\title{
EMPOWERING PESANTREN: A STUDY OF AL-GHAZALI'S THOUGHTS ON ISLAMIC EDUCATION
}

\author{
UMI ZULFA ${ }^{1}$ \\ Institut Agama Islam Imam Ghozali Cilacap
}

\section{Abstract}

Efforts to create peaceful world by upholding values of pluralism and to bring prosperity on earth by developing science and technology become very crucial and urgent. However, horizontal conflicts due to religious differences and technological abuses are still prevalent. This study provides an alternative design for Islamic education that is believed to be able to make life on earth more advanced, peaceful and prosperous with reference to al-Ghazali's thoughts. It reveals some possible ways to empower pesantren to meets the needs of students in the contemporary era, extracted from al-Ghazali's thoughts on shak, tawādu', subbah, mukhtalif al-alwān and the classification of knowledge. The study is qualitative research with descriptive analysis of literatures concerning education. In this paper, the author argues that such an ideal pesantren should uphold the characteristics of (1) inclusive religious education, (2) balanced religious and scientific development, (3) student-centered learning, and (4) entrepreneurial institution.

Upaya untuk menciptakan dunia yang damai dengan menjunjung tinggi nilai-nilai pluralisme dan membawa kemakmuran di bumi dengan mengembangkan ilmu pengetahuan dan teknologi menjadi hal yang sangat penting dan mendesak. Namun, konflik hor-

Corresponding author; email: ${ }^{1}$ umi.zulfa@iaiig.ac.id. 
izontal karena perbedaan agama dan penyalahgunaan teknologi masih lazim terjadi. Studi ini disajikan untuk memberikan desain alternatif untuk pendidikan Islam yang diyakini mampu membuat kehidupan di bumi lebih maju, damai dan makmur dengan referensi pemikiran al-Ghazali. Kajian ini mengungkap beberapa cara untuk memberdayakan pesantren untuk memenubi kebutuhan siswa di era kontemporer, yang diambil dari pemikiran al-Ghazali tentang shak, tawādu', șuḅbah, mukbtalif al-alwān dan klasifikasi pengetahuan. Penelitian ini adalah penelitian kualitatif dengan analisis deskriptif literatur tentang pendidikan. Dalam makalah ini, penulis berpendapat bahwa pesantren yang ideal harus menjunjung tinggi karakteristik (1) pendidikan agama inklusif, (2) pengembangan agama dan ilmiah yang seimbang, (3) pembelajaran yang berpusat pada siswa, dan (4) lembaga wirausaha.

Keywords: Al-Ghazali's thoughts; empowerment; Islamic education; pesantren.

\section{Introduction}

Indonesia is a democratic country that gives freedom to all its citizens to worship according to their respective religion and belief (UUD 1945 article 29, paragraph 2). The country also pays great attention to religious education equal to other types of education, as set forth in Law No. 20 year 2003 on the National Education System article 15 stating: the types of education include general, vocational, academic, professional, religious, and special education. The Government Regulation No. 55/2007 on Religious Education clearly explains how Indonesian government regulates religious education for its citizens. Article 1 paragraph 1 on the scope of religious education states:

"Religious education is an education that provides knowledge and shapes attitude, personality, and skills of the learners to practice their religious teachings facilitated by subjects or courses on all channels, levels, and types of education." 
The above regulation indicates that the government has thought of religious education for all its citizens through various channels, levels and types of education. That is, religious education in Indonesia can be conducted by formal and non-formal education, from elementary level to higher education organized by special religious educational institutions, such as pesantren and majelis taklim. In this paper, the religious education meant by the author is the Islamic education in pesantren.

It is important to note that the general assumption about Islamic education in Indonesia is still not pleasing as the education is merely able to make the learners individually pious, but is unable to make them socially pious. Consequently, the exclusiveness of religious followers leads to new problems, such as intolerance. This exclusiveness makes them assume that their patterns of behavior are the best, most beautiful, most important, and so on. This situation will gradually lead to the rise of violences in the name of religion. Through proper religious education, this issue is can be resolved.

Bambang Pranowo, for example, made a report about intolerance attitude in schools suggesting that radicalism is closely related to intolerance. Meanwhile, the Lakip survey shows that $62.7 \%$ of Muslim teachers and $40.7 \%$ of Muslim students reject the establishment of other religious places of worship in their neighborhood. $57.1 \%$ of the teachers and $36.9 \%$ of the students also refuse to tolerate religious celebrations performed by non-Muslims in their neighborhood. Interestingly, the survey also finds that $21.1 \%$ of the teachers and $25.8 \%$ of the students consider Pancasila no longer relevant to be the state ideology. The teachers and students consider the issues of the nation will be resolved only if the Islamic Sharia is applied in Indonesia $(65 \%)$. The Lakip survey also mentions that almost $50 \%$ of the students agree on radical acts in the name of religion (Suyatno 2013, 97). 
There are at least some factors of why the task of the Islamic religious education in Indonesia is considered unfinished yet, as intolerant attitudes among religious followers are still widespread. First, it is thought that theoretical knowledge of religious education is more emphasized than its implementation. The second is the assumption that religious education is merely a complement. The third is the lack of emphasis on the cultivation of moral values that support interreligious harmony. The fourth is the lack of reflection of the educational purposes. This way, attitudes such as mutual respect, sincerity, and tolerance towards religious and cultural diversity can be achieved in a plural society (Yahya 2010).

Such problems suggest that it is now the time religious education in pesantren be oriented to plurality or diversity education. The education must be able to promote inclusive values that share mutual respect among religious followers. In this context, the ideal values to empower pesantren are extracted from Al-Ghazali's thoughts, i.e. shak, tawādu', șụ̣bah, mukhtalif al-alwān and the classification of knowledge. This research uses a descriptive analysis, and it is part of library research in the field of education. The resources used by the author include books from academic publishers, articles from scholarly journals, data, primary sources, articles from popular publications, and other documents.

\section{Pesantren as Religious Education Institution}

The way to know pesantren may begin from knowing the meaning of the term, i.e. pesantren. Etymologically, pesantren comes from pe-santri-an which means the place of santris or students; dormitory where santris learn religion or; cottage. It is also said that pesantren comes from the word santri, that is, someone who learns Islam. Thus, pesantren means a place where people gather to study the religion of Islam (Dhofier 1994, 18). 
Later, pesantren terminologically is meant to refer to a religious social institution that becomes an educational vehicle for Muslims who want to explore religious sciences and knowledge. Pondok Pesantren in religious terminology is an Islamic education institution. However, pesantren has become a social icon in Indonesian society. This is because it has typical social characteristics: (1) the figure of kyai, (2) santri, (3) independent quality, and (4) strong social network among its alumni (Maksum 2015, $85)$.

In Indonesia itself, the explanation of pesantren is referred from the Regulation of the Ministry of Religious Affairs (Permenag 2012). According to this regulation, what is meant with pesantren is an educational unit held in the form of pesantren salafiyah, that is, a pesantren which conducts education using kitab kuning (literal: yellow book) and a teaching system set by kyai or tutors (Ministry of Religious Affairs 2012). This also means that, de yure, the government recognizes the pesantren as a traditional education institution, even though, de facto, there have been many modern and semi-modern pesantrens emerging.

Many sources state that pesantren is the oldest type of Islamic education institution and has long been rooted in the culture of Indonesian society. It is the center of study and deepening treasures of Islamic sciences and, at the same time, the center of Islamic propagation movement in society. Pesantren is also known as the guardian of Islamic orthodoxy. It is a unique educational institution, not only because of its long existence, but also because of the culture, method, and network applied by this religious institution. Besides, pesantren is sort of education system indigenous in Indonesia.

The existence of pesantren as one of the educational institutions in Indonesia, de yure, refers to the regulation as follows: (1) Law No. 20 of 2003 on National Education System, Article 
15 mentions: "the types of education include general, vocational, academic, professional, religious, and special education". In this context, pesantren belongs to a category of religious education organized by the community. (2) The Government Regulation No. 55/2007 on Religious Education Article 1, Paragraph 1 explains the scope of religious education: "Religious education is education that provides knowledge and shapes the attitude, personality, and skills of learners in the practice of religious teachings, and is implemented at least through the subjects or courses on all channels, levels, and types of education".

\section{Al-Ghazali's Thoughts on Islamic Education}

Al-Ghazali's complete name is Muhammad ibn Muhammad ibn Ahmad al Thusi Al-Ghazali. He was usually called Abu Hamid, nicknamed Zayn al-Din, and dubbed with Hujiat al Islam (the Islamic thinker). He was born in $450 \mathrm{H}$ and died in 505 $\mathrm{H}$ in Thus, Khurasan (Rosyad 2004, 113). As huijatul Islam, he has made many thoughts, which are broad and deep. In this context, the author will focus only on a few of his thoughts that are relevant to the discussion of this paper. In this case, his thoughts meant are concerned with shak (skeptic-methodological), tawādu', șuḅbah, mukhtalif al-alwān (IAIIG 2014, 5-6), and the classification of knowledge (Alwizar 2015, 143).

The first is shak. Shak or skeptic is a term used by Al-Ghazali to describe the situation he experienced at the time, that is when he had reached the highest phase in his life journey. Syak does not mean to doubt the truth of knowledge from God. It is precisely indicative of the process that must be passed in the search for knowledge; that is, before obtaining evidence that shows the ultimate truth of the science, the process of searching and discovering such knowledge should not stop (Al-Ghazāli 1975, 79; Al-Ghazālī, n.d., 8). This concept of shak will inspire the importance of conducting research and innovation continu- 
ously in order to find the true point of truth. If this is done in the context of Islamic educational institutions, including the higher education institutions with their duty to always do research, then science will continue to evolve to the point of truth that has been inscribed in the Quran.

The second is tawādlu'. The concept of tawädlu'advanced by Al-Ghazali means a respect for the truth. It means that our respect should refer to the object, not the subject. As long as the subject has the truth, the subject is entitled to respect. Here, the concept of tawādlu' by Al-Ghazali is different from the concept of tawādlu' in general (Al-Ghazālī 1975, [1] 82, 180). This concept of tawādlu' is expected to inspire secondary students, santris, or college students to always respect the truth (science), to be active through learning and researching in order to find the truth. Finally, this truth-seeking action becomes daily activity until the subject earns the highest degree together with the believers because of the possession of the truth. This is in accordance with Quran, Chapter al-Mujadalah: 11.

The third is subbah or togetherness. Humans are cultured beings. One can be said to be cultured if he is able to live by promoting the value of togetherness or suḅah. Togetherness itself will not be achieved without recognition of the diversity that exists in society. Therefore, to be in a circle of togetherness, it requires recognition of the diversity that exists in society. In this case, Al-Ghazali teaches Islamic doctrines gentle and polite, not hard and sharp. God is presented not only as the Firm Substance as the fiqh scholars declare, but also as the Most Gracious and Most Merciful. Amid the tendency of a group of Muslims who preach Islam through violent ways, the doctrines of Sufism promoted by Al-Ghazali become relevant (Ghazali 2016, 82-86).

Muslims who are able to demonstrate courtesy, not harshness and cruelness even when dealing with adherents of other 
religions, show that they have been able to appreciate the diversity that exists in the real life so that they can live together in the diversity. This is șḅbah. If this șubbah attitude is developed in the context of world-class educational institutions full of diverse communities, then the educational institutions will be able to produce graduates who have the attitude and soul of șubbah, and eventually, the world becomes peaceful because it is filled and prospered by human beings who have soul and attitude of suḅbah. The world-class educational institutions meant are the pesantrens.

The fourth is mukhtalif al-alwān (diversity). Diversity is a form of recognition of the differences. Recognition of this difference is a condition of achieving togetherness. Through this recognition of diversity, peaceful coexistence becomes possible, al-ta'ayush bi al-silmi. In this sense, suḅbah will always coexist with the mukhtalif al-alwān. The prerequisite to be able to live together peacefully, each individual and group must have an attitude acknowledged in the difference. The educational institutions that are able to indoctrinate their students to have the attitude of recognizing the differences will result in graduates with subbah attitude that promotes peace in the world.

The last is the classification of sciences. Al-Ghazali divides sciences seen in term of importance into two groups. The first is the fardu 'ain science that must be studied by every individual, such as the science of religion and its branches, and the science that comes from the book of Allah swt. The second is the fardu kifäyah science, that is, the one used to facilitate worldly affairs, such as arithmetic, medical science, engineering, agricultural sciences, and industry (Alwizar 2015, 143).

If viewed from the aspect of importance, clearly Al-Ghazali reminded of the importance of integrating between religious science as a compulsory science that will lead people to the salva- 
tion of the hereafter and secular science as a provision to maintain the sustainability of human beings and all creatures that exist on earth.

\section{Developing an Ideal Model of Pesantren}

The model of an ideal pesantren based on Al-Ghazali's thoughts offered as an alternative model of the future pesantren education is a model developed with theoretical and empirical foundations as described in the following explanation.

\section{Figure 1}

Platform for the development of an ideal pesantren model

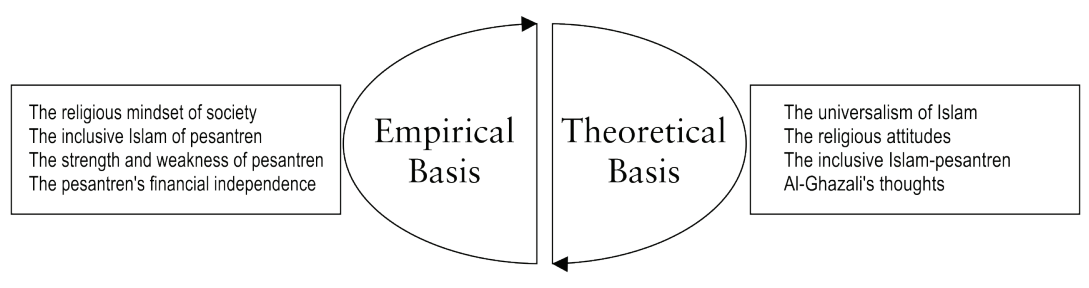

\section{Empirical Basis}

The first is the style of religious thinking of the community. Basically, the style of religious thinking can be divided into three, namely exclusive, inclusive, and liberal. This style of thinking does not see whether the society is a conservative or modern society. This fact is reinforced by the Rahmat's research on the college students that $52,7 \%$ of respondents are exclusive in religious thinking, $26.4 \%$ are inclusive, $7.3 \%$ are liberal, and $13.6 \%$ are unclear (Rahmat 2012, 25). This shows that even the students who should be able to think moderate are still exclusive in religious thinking. Their association with either modern or traditional age does not guarantee the inclusiveness of their religious thinking, vice versa with pesantren community, which is often categorized as a traditional society but in fact is even able 
to show an inclusive religious mindset. This is also reinforced by the results of a research by Bambang Pranowo concerning the attitude of intolerance at school, which according to the Lakip Survey, nearly $50 \%$ of students agree on radical acts in the name of religion (Suyatno 2013, 97).

The empirical condition of Inclusive Islam in pesantren, among others, can be seen from a research by Ali Maksum. According to Maksum, both in modern and salaf pesantrens, the understood and actualized Islam is Islam that is inclusive, friendly, not rigid, and moderate, that is, Islam with different nuance and full of multicultural values (Maksum 2015). In line with the inclusive Islamic education in pesantren, this indicates that pesantren also carries out peace education.

Francoise $(2017,60)$ maintained that to judge a pesantren as the source of peace education can be viewed by the number of its kyais and santris who are active in peace activities, for example in Gontor Modern Pesantren and most of pesantrens in Madura island, they are always contributing and participating in peace activities, they are active in national ceremonies, workshops on peace education, meeting about Pancasila as one of schools subject, and learning exchange with other schools. The alumni of pesantren also use social media on the Internet to spread peace da'wa.

The empirical condition of the weakness and strength of pesantren (Rindanah 2013; Hidayati 2017, 9; Maksum 2015, $84-94)$ is presented in table 1.

The practice of education in both pesantrens, i.e. salaf and khalaf, has weaknesses and strength. If examined more carefully, even the weakness has the opportunity to become strength. From the above description, at least we can sum up the following aspects. 


\section{EMPOWERING PESANTREN}

Table 1

The weakness and strength of salaf (traditional) pesantren

\begin{tabular}{|c|c|}
\hline Weaknesses & Strengths \\
\hline $\begin{array}{l}\text { - Closing itself to the changing times, } \\
\text { and being conservative in responding to } \\
\text { modernization } \\
\text { - More emphasizing the fiqh, tașawuf and } \\
\text { grammatical sciences centered on the } \\
\text { classic books } \\
\text { - Emphasizing rigid and literal transla- } \\
\text { tion } \\
\text { - There is a decrease in the quality and } \\
\text { quantity of the salaf pesantrens } \\
\text { - The use of traditional learning methods } \\
\text { such as sorogan, bandungan (halaqah), } \\
\text { wetonan and memorization } \\
\text { - Lack of emphasis on the importance of } \\
\text { reading and writing } \\
\text { - The dominant role of kyai as the main } \\
\text { source of learning }\end{array}$ & $\begin{array}{l}\text { - A strong reverence of the sant- } \\
\text { ris for the kyai } \\
\text { - The right place to create Is- } \\
\text { lamic cadres with noble char- } \\
\text { acter and qualified to religious } \\
\text { studies, such as fiqh, tașawuf, } \\
\text { or grammatical sciences } \\
\text { - As a central place to study the } \\
\text { religious sciences } \\
\text { - An educational place with no } \\
\text { - social strata } \\
\text { - Teaching the spirit of demo- } \\
\text { cratic, tolerant, cooperative, } \\
\text { unified, equal, confident and } \\
\text { courageous life } \\
\text { - An inclusive Islamic education }\end{array}$ \\
\hline
\end{tabular}

Table 2

The weakness and strength of khalaf (modern) pesantren

\begin{tabular}{|c|c|}
\hline Weaknesses & Strengths \\
\hline $\begin{array}{l}\text { - Lack of typical char- } \\
\text { acteristics of pesantren } \\
\text { as an indigenous edu- } \\
\text { cational institution in } \\
\text { Indonesia } \\
\text { - The religious sciences } \\
\text { are no longer given } \\
\text { intensively as in salaf } \\
\text { pesantren } \\
\text { - Lack of face-to-face } \\
\text { interaction with kyai } \\
\text { because there are } \\
\text { ustadhs who are asked } \\
\text { to take care of the san- } \\
\text { tris. From here, inner } \\
\text { contact between the } \\
\text { santris and the kyai } \\
\text { will be difficult } \\
\end{array}$ & $\begin{array}{l}\text { - There are significant changes in the system, } \\
\text { methods, and curriculum of pesantren } \\
\text { - Classical instructional system of learning (class- } \\
\text { room teaching) and integrated curriculum are } \\
\text { adopted with certain adjustments } \\
\text { - Open to respond the changing times } \\
\text { - The spirit to support the development of educa- } \\
\text { tion in Indonesia is given not only in religious } \\
\text { education but also in non-religious one. } \\
\text { - The establishment of madrassas and even uni- } \\
\text { versities to develop both religious and secular } \\
\text { education in the pesantren environment } \\
\text { - Being able to change the conservative attitude } \\
\text { into more flexible one } \\
\text { - The output or graduate is various, not restrict- } \\
\text { ed to a religious teacher. The graduates now } \\
\text { penetrate into the world of politics, economy } \\
\text { and some other fields }\end{array}$ \\
\hline
\end{tabular}

First is related to institution. The shutting-out from the outside world for the salaf pesantren and the loss of identity for the khalaf pesantren are indeed the main institutional weakness of 
pesantren. This condition is obviously contrary to fikrah (concept) or harakah (movement) of pesantren as an Islamic education institution in the archipelago. This means that if referring to the fikrah and harakah, pesantren has a great opportunity to become a world-class educational institution.

In this case, the attitude that should be maintained by pesantren in order to develop and internationalize itself as a worldclass educational institution is that pesantren should prioritize the moderate (tawāsut) fikrah with the orientation of making improvements as its harakah, not just imitate from the outside world. That is, pesantren as a sub-system of the national education should quickly respond to the changes and dynamics of the demands of the world, both from the aspect of Islamic religious education and from secular sciences and technology. However, the pesantren should not abandon its typical identity.

Second is related to the curriculum. The curriculum aspect meant here is the content or the material as a product of the methodology; it is a way of achieving the truth from science. Here is the explanation. Third is related to the content or material. Curriculum in educational institutions is the main menu that describes the profile of graduates in relation with the market. Most salaf pesantrens emphasize the fiqh, tașawuf, and grammatical sciences a.k.a religious sciences with traditional learning method. In the other hand, the khalaf pesantrens give is less emphasis on religious sciences.

In this sense, thinking of tawāsut or moderate way becomes important, given the importance of pesantrens particular and Islamic educational institutions, in general, today as they are expected to become an alternative or solution for morality problems in the society. Through a good, focused and deep Islamic education, such problems can be disallowed. However, pesantren must also redesign the curriculum, especially related to the 
science and technology that became the booster of world civilization. This means that curriculum integrating science-technology with religious education will become a crucial factor of the rise of Islamic education, especially the pesantrens in Indonesia.

Fourth is related to methodology. The methodology should consider the ability and characteristics of the santris, such as sorogan, bandungan, bahth al-masā'il and so forth. The educational system should facilitate the characteristics of learners. Fifth is related to the educator or kyai. Kyai is the key figure as he becomes the main source of learning in pesantren. The kyai is considered to be as the heir or successor of the prophet. That is why the figure of kyai is usually a knowledgeable man. Islam as a religion that upholds the truth highly appreciates people who are knowledgeable; they place a high rank in the sight of God. This means that the respect is not caused by the physical appearance of the kyai, but the ownership of science and knowledge. In education, anybody or anything having valid instructional information can be a source of learning, and the kyai or even the santri is no exception.

Sixth is the financial independence of pesantren. The chance owned by pesantren to be a world-class education model also depends on its independence financial matter, such as in Pesantren Sidogiri of Pasuruan. As one of the top twenty pesantrens in Indonesia, this salaf pesantren still maintains the educational system from Madrasah Diniyah (MD) up to the university level or Ma'had Ali named Tarbiyatul Mualimin. The pesantren's trademark is found in the financial independence as it has a business built by the pesantren, such as a minimarket (Mart) named Koperasi Sidogiri, a financial institution called Bait al-Māl wa al-Tamwil (BMT), and many other businesses.

According to the data of the Ministry of Religious Affairs in $2003-2006$, of the 16,015 pesantrens in Indonesia, $13.23 \%$ is 
concerned with trade, $15.03 \%$ with agribusiness, and 10, 92\% with handicrafts (Sudibyo 2011, 55-57). Similarly, pesantren in Muslim minority areas like in Papua, in addition to religious knowledge, pesantren also equips entrepreneurship skills, such as in agriculture, plantation and fishery as the main choice, and cooperatives and shops, farms, and buying and selling as the special options (Wekke 2017, 20).

Based on some empirical facts above, we can conclude things as follows:

First, Islamic education in Indonesia through the existing regulations become the right for every Indonesian citizen who is Muslim and can be obtained through various levels, paths and types of education. This means that the government has improved the service of Islamic religious education for its adherents. More specifically, because Islam is the religion of the majority, then Islamic religious education should be a pioneer for the implementation of religious education that is inclusive, peaceful and increasingly strengthens brotherhood not only in the name of nation, state, or religion but also in the name of God creatures in charge of prospering this beloved earth. In this case, the religious educational institution which consistently carries out its education process is the pesantren. In other words, pesantren is an inclusive religious education. This fact will open the eyes of the world that it is the pesantren that teaches how to respect differences (șubbah), including religion. It obviously refuses the assumption that pesantren produces terrorists.

Second, campus as one of the institutions that can provide religious education services, either through curricular or through extracurricular activities, is not automatically able to guarantee the formation of students who have an inclusive mindset. This means that the inclusive religious education remains in the pesantren. Third, pesantren as an Islamic educational in- 
stitution has its own peculiarities. The salaf labeling does not always indicate that a pesantren is not able to reconcile with modernity. From this perspective, pesantrens in Indonesia have the opportunity to be developed into a world-class educational institutions by demonstrating its ability to educate their santris to be a person who has a high fighting spirit (entrepreneur), in addition to economic power built by the institution, i.e. pesantren (entrepreneur institution). This means that pesantren is an entrepreneur institution that not only trains the santris to be a true entrepreneur but also serves as an entrepreneur institution to finance the institution and empower the santris and the surrounding community.

Fourth, pesantren, especially the khalaf pesantren, offers programs needed by the international community, i.e. secular sciences, in addition to religious science. This means that pesantren is an educational institution that balances human needs, that is, the secular science developed for worldly orientation and the religious science learned to prepare them to live in the world of immortality, i.e. life of the hereafter. This way, pesantren serves as the provider of secular and religious education.

Fifth is related to the kyai position and the method of education in pesantren. In instructional paradigm, the kyai position as the educator cannot be replaced by anyone or anything. This is because he is responsible for the truth of science-knowledge, in addition to the role model or uswah hasanah, for his santris. $\mathrm{He}$ does not restrict the rights of his santris in learning activities in pesantren. Here, the kyai uses a learning method that empowers the santris' skills, such as sorogan, bandongan, bahth al-masail, biwār, uswah hasanah, and so on. This is evident that pesantren is able to develop an educational method that empowers its santris. This is in line with the paradigm of learning using a method as an external factor that contributes to the success of 
student learning. A method should give students the opportunity to learn and develop (student center learning).

In pesantren, the position of the kyai is not to dominate learning activities (teacher center learning), but to facilitate the empowerment of students and to clarify the truth of science. Kyai has the power of expert judgment and uswah hasanah so that his position can not be replaced by any sophisticated technology. Therefore, it can be concluded that pesantren places the students as center of learning with the use of empowering methods, while the kyai or teacher serves as expert judgment and uswah hasanah irreplaceable by any technology.

Based on the analysis of these empirical conditions, it is recommended that pesantren has the opportunity to be developed into an ideal model of pesantren. This means that the re-design of an ideal model of pesantren based on empirical facts is an offer as well as an answer to various issues related to the challenges of the changing times, especially related to religious education, religious life, and human civilization. Several reasons are provided as follows:

First, public is becoming aware of the importance of religion as a solution to the various problems faced by humans due to the negative impact of the progress of Science and Technology. Second, world citizens are becoming aware of the importance of creating world peace. This mission can start with an inclusive religious education that will produce graduates that appreciate diversity and are able to live peacefully in diversity. This situation will ensure the human responsibility as caliphate on earth. Third, age of the earth that is getting old and porous because it is always undermined by human greed will be relatively longer if humans do rejuvenation of the earth. This can only be realized if humans have a high work ethic and fighting spirit (entrepreneurship) to care for the earth for its survival and all creatures that 
are in it. Fourth, economic power as one of the pillars of world education will be realized from the great contribution of the educational model given by pesantren that teaches the economic independence, namely economic entrepreneurship.

The result of this empirical study is an ideal model of pesantren with characteristics of inclusive religious education, balanced secular and religious sciences, and entrepreneurship. It can be applied in any part of the world to create inclusive, religious, genius, and entrepreneurial graduates.

\section{Theoretical Basis}

The first theoretical basis deals with the universalism of Islam. One of the features of Islamic thoughts in Indonesia is internationalism or universalism of Islam. The idea of internationalism or universalism of Islam argues that Islam is essentially universal. Therefore, it is a fixed dictum (Qodir 2004, 46). This means that Islam as a universal religion has the nature to be accepted by citizens of the world. Its teachings can be contextualized in all the matters of human life, including pesantren education.

The second deals with the religious attitude. In general, religious attitudes toward the religion of others can vary. In this case, Hans Kung points out four categories of people's attitudes towards other religions. He calls them fort strategy, ignoring strategy, embracing strategy, and ecumenical strategy. In fort strategy, it departs from the assumption that only one particular religion is true, while other religions are not. Therefore, religious peace will only be achieved through the guarantee of one particular religion.

In ignoring strategy, it departs from the assumption that the essence of truth is essentially non-existent, because all religions are essentially correct in their own way. Therefore, religious peace will be best achieved when differences and contradictions 
are ignored. In embracing strategy, it departs from the assumption that only one religion is true, and all the religions that have developed in history have some truth in them. Therefore, religious peace will be best achieved when there is integration of all religions. In ecumenical strategy, it departs from various religious abuses that have occurred so far. It is related to the humanity perspective before God, the Absolute.

Of the four strategies above, it is ecumenical strategy that is relatively capable of providing solutions to the problems of interreligious relationships. This strategy uses humanitarian criteria as a tool to relate with adherents of other religions. In other words, inclusiveness in the interreligious relation can be practiced through ecumenical strategy. This is because the inclusive religious attitude is very important in a very diverse society. This means that inclusiveness becomes a manifestation of tolerance in a plural society, including religious tolerance: "... religious tolerance is asking for the willingness to allow different parties to the implementation and develop of worship place ..." (Suryono 2016, 408).

The third deals with pesantren as an inclusive Islamic education in the Archipelago. Pesantren is an Islamic educational institution that shows the existence of Islam in the Archipelago. This is because the penetration of Islam Nusantara itself is manifested through a process of the embodiment of Islamic values from local cultures. In fact, Islam Nusantara is built by injecting Islamic values into the local cultures, taking Islamic values to enrich the local culture, or filtering the cultures to fit the Islamic values. The process is possible because in Islam there is a principle of fiqh al-'adat al-muhakkamah, that is, custom may become a law, in addition to the development of understanding the nas, al-Quran and Hadith. The principles of fiqh and such a development are solely aimed at the attainment of maqāsìd al-sharī'ah (the purpose of the sharia), namely the realization of the benefit 
(mașlahah) of humans in the world and the hereafter. It includes the five main principles (al-kulliyyāt al-khams), namely bifz aldīn, hifz al-'aql, hifz al-nafs, hifz al-māl, and hifz al-'ird (Mustofa 2015).

This means that Islam Nusantara occurs through the process of acculturation of Islamic culture with indigenous culture. In this context, Karim categorizes the acculturation of Islamic culture into three phases, i.e. natural, educational and organizational (Karim 2007, 147-50). In (1) the natural phase, Islam brought its cultural values through the traders who came to the Archipelago with the main goal to trade, besides to spread religious teachings. In (2) the educational phase, Islamization was conducted by preparing cadres, i.e. muballigh or preachers due to the need to spread Islam to all corners of the Archipelago. This was done through Islamic schools and pesantrens, so that the cultural mixing occurs only between the Islamic education and the indigenous culture. Finally, (3) the organizational phase is the implication of the second phase. While the establishment of Islamic schools and pesantren was usually done in the suburbs, those who lived in the city took a different way.

Those who lived in the city established madrassas or Islamic schools that were built by Islamic institutions, such as $\mathrm{Mu}$ hammadiyah, Persis, NU and so on, in a modern system. As an organization, there must be rules that must be met, such as matters related to organization, administration, communications, management, finance, and so forth. Many of them were adapted from Western culture. This means that the process of establishing Islamic institutions or organizations is a process of mixing between Western culture and Islamic culture filtered carefully. This led to a new modern way of life.

The second theory is presented by Uka Tjandrasasmita $(2009,21)$. According to him, the Islamization process in the Archipelago takes place through a diverse network that naturally 
benefits each party, i.e. the Muslims who come and spread Islam to various places in Malay (archipelago) and the people who accept or convert to Islam as their religion. Broadly speaking, the spread of Islam and its process can be done through various channels, such as trade, marriage, bureaucracy, education, sufism, art, and others.

The fourth deals with Al-Ghazali's thought, i.e. shak, tawādu', șụbah, mukhtalif al-alwān and the balanced worldly and heavenly sciences. Besides theories mentioned before, other reference mentions that the pattern of Islam Nusantara is strongly influenced by the thoughts of Al-Ghazali, especially in tașawuf characterized with the polite attitude and the reduction of legal-formal attitude in Muslims life (Ghazali 2016). This can be used as a capital in Indonesian education to produce an output that always appreciates the differences and pluralism in the society. This means that pesantren as an Islamic educational institution capable of forming output or graduates with attitude to always appreciate the various differences and plurality is an educational institution capable of implementing the inclusive education.

In addition to the polite attitude, Al-Ghazali's second thought that we can refer to in this context is shak or skeptical. Syak is a term used by Al-Ghazali describing his situation at that time, that is, when he had reached the highest phase of the achievement of worldly existence. Shak meant by Al-Ghazali is a skeptical-methodological attitude. Syak or being skeptic in the process of truth-seeking is a condition that should be fulfilled before one obtains valid proof of truth. This way, the truth will be a valid science.

Shak will also drive the truth seekers to always innovate to develop science in scientific norms in line with religious doctrines which are transcendent. In fact, shak will put rationality 
as a balancing dimension of the transcendental science. With this shak, the chance to develop science and technology based on the Quran in order to prosper and glorify the earth will be possible.

In line with skeptical-methodological attitude, tawāḍ' is the next attitude to be owned by learners, scientists, and Muslim society in general. Tawāḍ' meant by Al-Ghazali refers to object, not subject, that is, to be submissive to the truth, not to the person. As long as the person has the truth, we are obliged to listen to him. If this attitude is developed within the context of pesantren education, obedience to the truth becomes possible.

Although shak and tawādu' have been internalized, but șuh $b a b$ or togetherness is not manifested in a pluralistic life, peaceful life on earth will not be realized. Al-Ghazali in this case pays great attention to șuhbah. In fact, șuhbah becomes a characteristic of human beings. In a cultural context, a person is said 'cultured' if he is able to live in togetherness, and this togetherness will not be achieved without recognition of the diversity that exists in society. Therefore, it is important to take recognition of the existing diversity.

In this case, Al-Ghazali teaches gentle and polite attitude, not a hard and violent one. God is presented as not only the Firm Essence as the fiqh scholars declare, but also the Most Gracious and Most Merciful. Amid the tendency of a group of Muslims who like to preach Islam through violent ways, the doctrine of Sufism that Al-Ghazali presents is very relevant. In the view of Al-Ghazali, if God is the Beloved, man is the Sālik, who is walking towards God. Therefore, șuhbah can be formed if the humans have an attitude of mukhtalif al-alwān (recognition to differences).

The five thoughts introduced by Al-Ghazali will be more perfect if Muslims place those thoughts while integrating the worldly science which is fardu 'ain with the heavenly science 
which is fardu kifāyah (Alwizar 2015, 143). The task carried by humans as khalifah fi al-'ard will be realized if they are competent on both sciences. The mastery of religious science becomes a primary need since they are His creature, so that religious science is required in order to be able to understand what His will is. Moreover, as khalifah fi al-'ard, mastering those to sciences is a must to carry out the main task to spread prosperity on earth.

These six thoughts of Al-Ghazali are specifically able to be an inspiration for the efforts of Muslims in the world to formulate an educational institution that will be able to produce its graduates become khalifah fi al-'ard, that are able to make the earth safe, peaceful, and prosperous, and to make the inhabitants listen to the essence truth.

Based on the empirical-theoretical basis above, we find the following prepositions: (1) pesantren is an inclusive religious education organizer, (2) pesantren is an entrepreneurial institution, (3) pesantren is an Islamic educational institution that balances between secular and religious science education, (4) the pesantren puts students as center of learning using the empowering methods, while the kyai or teacher serves as expert judgment and role model or uswah hasanah irreplaceable by any sophisticated technology, (5) the polite style of Al-Ghazali's thought which emphasizes the șuḅah and mukhtalif al-alwān, and upholds the methodological skepticism and tawa $d u$ in the scientific context will be able to offer the development of high-tech science that is friendly to the difference of creatures and the existence of the earth. It is a balance between the secular science which is fardu kifāyah and religious science which is fardu 'ain. Gradually, it will be the inspiration of the implementation of an inclusive and science-based education equipped with religious values, and (6) the high demand for good graduates needs educational institutions that produce an inclusive, religious and intelligent person having entrepreneurship spirit. 
From these prepositions, the conceptual model which is composed and offered is the ideal model of pesantren.

Figure 2

The ideal model of pesantren

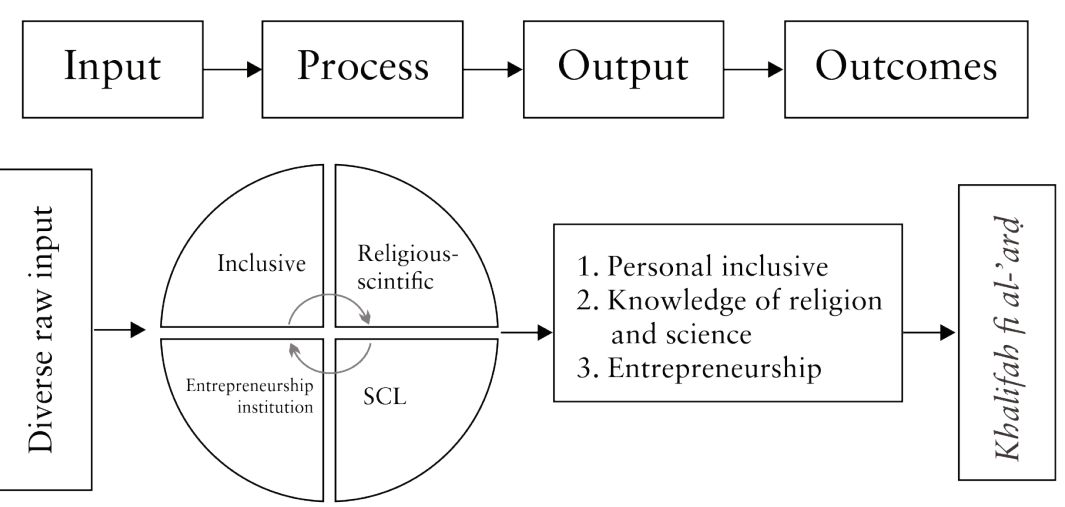

As a new conceptual model, this model has characteristics: inclusive, religious-scientific, student-centered learning and entrepreuneurial institution in order to support the management system to ensure the development of the ideal model of pesantren.

Inclusive meant here is pesantren as an educational institution that represents the world's diverse citizens in term of race, nation, religion, etc. This is based on the inclusive Islamic religious education resulting in graduates with inclusive religious attitudes that lead to the peaceful world.

Religious-scientific means that the pesantren as an educational institution balances the secular science, such as technology, with the religious sciences that are based on the attitude of developing science and technology using skeptic-methodological approach and tawadlu attitude oriented for life not only in this world but also in the hereafter. With these characteristics, pesantren will be able to produce a balanced graduate between the mastery of religious sciences and general sciences. Science 
and technology are mastered and developed while maintaining religious values. This way, ownership of science and technology which is based on religious morals will make people trustworthy khalifah on the earth, not the destroyers of the earth. This can be fulfilled if the pesantrens conducts their education to the higher education level, university.

Student-centered learning meant here is that in carrying out the process of education, pesantren uses the learning paradigm. Pesantren puts students as the center of learning with the use of empowering methods, while the kyai or teacher serves as expert judgment and role model or uswah hasanah irreplaceable by any sophisticated technology.

Enterpreuneurial institution means that pesantren is an institution that educates its santris to have enterprenership spirit, and proves itself as an entrepreneurial institution. Therefore, pesantren will be able to produce graduates who are self-motivated and always creative to realize prosperity on the earth. The ideal model of pesantren that is consistently carried out is expected to produce an output that characterizes an inclusive, religious and intelligent person having enterpreneurship spirit and is able to responsibly handle the duty as khalifah fi al-'ard.

\section{Conclusion}

Based on the research findings and discussion, this study concludes that pesantren promotes inclusive religious education and entrepreneurial learnings. Such a model of pesantren keeps a balance between secular sciences and religious sciences, puts students as the center of learning, and uses empowering methods, while the kyai or teacher serves as expert judgment and role model or uswah hasanah irreplaceable by any sophisticated technology. The pesantren adopts Al-Ghazali's thoughts emphasizing the sub̧bah and mukhtalif al-'alwān, and upholds the methodological skepticism and tawā $d u^{\prime}$ in the scientific context. 
It is believed that the thoughts will be able to develop a high science-technology that is friendly to the plural society and the maintenance of earth. It also becomes the inspiration for the implementation of an inclusive and science-based education. This matches with the high demand for the needs of graduates of educational institutions to produce an inclusive, religious and intelligent person having enterpreneurship spirit. This conclusion is then developed conceptually into an ideal model of pesantren which has four characteristics, namely: (1) inclusive religious education, (2) balanced religious and scientific development, (3) student-centered learning and (4) entrepreneurial institution. These four characteristics will make promising output or graduates of the ideal model of pesantren, which are inclusive, religious and intelligent person having enterpreneurship spirit as khalifah fi al-'ard.

\section{Bibliography}

Al-Ghazālī, Abū Hāmid Muhammad. n.d. Al-Munqidh Min AlDalāl. Andalusia: Dār al-Andalūs.

—. 1975. Ihya' 'Ulūm Al-Dìn. Beirut: Dār al-Fikr.

Alwizar. 2015. "Pemikiran Pendidikan Al-Ghazali.” Jurnal Potensia 14 (1).

Dhofier, Zamakhsyari. 1994. Tradisi Pesantren: Studi Tentang Pandangan Hidup Kiai. Jakarta: LP3ES.

Francoise, Jeanne. 2017. "Pesantren as the Source of Peace Education." Walisongo: Jurnal Penelitian Sosial Keagamaan 25 (1): 41. doi:10.21580/ws.25.1.1161.

Ghazali, Abdul Moqsith. 2016. "Corak Tasawuf Al-Ghazali Dan Relevansinya Dalam Konteks Sekarang.” Al Tahrir Jurnal Pemikiran Islam 13 (1).

Hidayati, Noorazmah. 2017. "Pemertahanan Kekhasan Pengajaran Kitab Kuning Pada Pondok Pesantren Darussalam 
Martapura Kalimantan Selatan (Telaah Aspek Linguistik Dan Sosiolinguistik).” Madania 21 (1).

IAIIG. 2014. "SK Rektor Tentang Core Values Keghozalian.” Cilacap: IAIIG Cilacap.

Karim, M. Abdul. 2007. Islam Nusantara. Yogyakarta: Pustaka Book Publisher.

Maksum, Ali. 2015. "Model Pendidikan Toleransi Di Pesantren Modern Dan Salaf." Jurnal Pendidikan Agama Islam 3 (1): 84-93.

Mustofa, Saiful. 2015. “Meneguhkan Islam Nusantara Untuk Islam Berkemajuan: Melacak Akar Epistemologis Dan Historis Islam (Di) Nusantara." Epistemé: Jurnal Pengembangan Ilmu Keislaman 10 (2): 405-34. doi:10.21274/ epis.2015.10.2.405-434.

Permenag. 2012. "Peraturan Menteri Agama Republik Indonesia No. 3 Tentang Pendidikan Keagamaan Islam.” Jakarta.

Qodir, Abdul. 2004. Jejak Langkah Pembaharuan Pemikiran Islam Di Indoensia. Bandung: Pustaka Setia.

Rahmat, Munawar. 2012. "Corak Berpikir Keagamaan Mahasiswa (Ekslusif, Inklusif Dan Liberal)." Jurnal Pendidikan Agama Islam Talim 10 (1).

Rindanah, Rina. 2013. "Geneologi Pesntren Benda Kerep Dan Pesantren Buntet Cirebon: Suatu Perbandingan.” Holistik 14 (2): 215-29.

Sudibyo, Rahmad Pulung. 2011. "Integrasi, Sinergi Dan Optimalisasi Dalam Rangka Mewujudkan Pondok Pesantren Sebagai Pusat Peradaban Muslim Indonesia.” Jurnal Salam 13 (2): 49-65.

Suryono, Hassan. 2016. "The Reconstructio of Religious Education into Community's Legal Life.” Walisongo: Jurnal Penelitian Sosial Keagamaan 24 (2): 401. doi:10.21580/ ws.24.2.1087. 
Suyatno. 2013. "Multikulturalisme Dalam Sistem Pendidikan Agama Islam: Problematika Pendidikan Agama Islam Di Sekolah.” ADDIN 7 (1). doi:10.21043/addin.v7i1.571.

Tjandrasasmita, Uka. 2009. Arkeologi Islam Nusantara. Jakarta: KPG.

UUD. 1945. Undang-Undang Dasar 1945, Article 29, Paragraph 2. Indonesia.

Wekke, Ismail Suardi. 2017. "Integrasi Pendidikan Islam Dan Pembelajaran Kewirausahaan Di Pesantren Minoritas Muslim.” Fenomena 9 (1).

Yahya, Muhammad. 2010. "Pendidikan Islam Pluralis Dan Multikultural.” Lentera Pendidikan 13 (2): 175-91. 
This page intentionally left blank 